\title{
DISTRIBUTION OF MASSES AND PRESSES ON AXLES AND WHEELS AND VEHICLES' PROPERTIES
}

\author{
Piotr Rybak, Andrzej Wiśniewski \\ Military University of Technology \\ gen. Sylwestra Kaliskiego Street 2, 00-908, Warsaw, Poland \\ tel.: +48261839 531, fax: +48261837370 \\ e-mail:piotr.rybak@wat.edu.pl,wisniewski.andrzej@wat.edu.pl
}

\begin{abstract}
One of the most important parameters affecting traction properties as well as driving safety, especially with regard to vehicles with special purpose, is the distribution of wheel and axle loads on the ground. This issue should be taken into account during the process of creating new vehicles as well as during the modernization process. In the first case, it is quite simple because the mass distribution is shaped already in the design phase. In the second case, the problem is more complex, because with modernization solutions we enter an already existing structure. Modernization basically assumes improving the performance and capabilities of the vehicle with possibly small changes in its base structure. Thus, it imposes important boundary conditions. The article presents the methodology of measurement and selected results of measurements of mass distribution as well as wheel and axle loads of selected motor vehicles during their advanced modernization (STAR 266 cars to the version STAR 266M2 and Honker 2000 to the version Honker M-AX). Modernizations carried out by Autobox Innovations Ltd. Lim. Par are mainly focused on increasing the traction of vehicles, traffic safety, and driving comfort. Measurements were made at the above-mentioned company.
\end{abstract}

Keywords: car, mass, pressures, properties

\section{Introduction}

Military vehicles intended for use in special applications are dedicated to tasks in the production process or often subjected to modernization processes. The need to improve them is the result of aging of the applied construction solutions, the need to match standards to modern solutions or to meet user requirements. Regardless of the inspiring sources, many new technical solutions are implemented that facilitate the work of the driver and allow increasing the efficiency of operation in the assumed conditions. A certain side effect of this process is the increase in vehicle weight. It should be noted that one of the most important parameters affecting traction and driving safety, especially for vehicles with special purpose, is the distribution of wheel and axle loads on the ground. This issue should be taken into account during the process of creating new vehicles as well as during the modernization process. In the first case, it is quite simple because the mass distribution is shaped already in the design phase. In the second case, the problem is more complex, because with modernization solutions we enter an already existing structure. Modernization as a rule assumes improvement of vehicle performance and properties with possibly small changes in its base structure. Thus, with significant boundary conditions imposed at the entrance, the process should be carried out without violating them in an efficient and effective manner.

The article presents selected elements of the methodology of measurements and tests of vehicle mass distribution as well as the results related to the determination of the pressure distribution on wheels and axles in the aspect of impact on traction properties and vehicle traffic safety.

\section{Tasks and requirements for special cars}

The main task of special cars (from the group of lorries, personal-trucks, personal-terrain, etc.) 
is to transport equipment and people to the destination and provide them with the implementation of complex projects. General requirements for lorries are included in national and international standards. The requirements included in them relate mainly to weight, dimensions, driving speed, noise level, emissions of toxic compounds in the exhaust, braking system efficiency, driver's workplace, impact strength of the cab and others.

The standard provisions stipulate that the axle load must not exceed $80 \mathrm{kN}$. This is due to the fact that the durability of road surfaces is strictly conditioned by the technology of road construction. However, it is allowed to raise it to $100 \mathrm{kN}$ on specific types of roads. However, these requirements do not apply to special vehicles.

The weight limits of the vehicle as well as its dimensions result mainly from the load-bearing capacity and dimensions of roads, bridges, viaducts, or tunnels as well as the location of the tram or railway network cables. It is required that the permissible gross vehicle weight does not exceed [2-6]:

- a single vehicle with the exception of the semi-trailer:

a) biaxial $-16 \mathrm{t}$,

b) with the number of axles greater than two $-24 \mathrm{t}$,

- an articulated vehicle or a pledge:

a) with an axis number of no more than four $-32 \mathrm{t}$,

b) with the number of axles greater than four $-42 \mathrm{t}$,

- national roads marked with single-digit and two-digit numbers,

- sections of national roads marked with three-digit numbers with signs with a border composed of white and black squares,

- sections of roads marked with prohibition signs for vehicles with axle loads above $100 \mathrm{kN}$,

- roads lying along the roads mentioned above and on regular bus routes within the administrative boundaries of cities.

The main dimensions of vehicles in force in the country:

- the length of a articulated vehicle $16.5 \mathrm{~m}$,

- the length of the assembly consisting of a motor vehicle and a trailer $18.75 \mathrm{~m}$,

- vehicle height should not exceed $4.0 \mathrm{~m}$,

- vehicle width should not exceed $2.55 \mathrm{~m}$.

Permissible axle load:

1) According to the applicable regulations, at least $25 \%$ of the weight of the whole vehicle or vehicle combination must fall on the driving axle or axles (applies to all vehicles registered after March 31, 1998).

2) The permissible load on the driving axle of a lorry must not exceed 11.5 tonnes.

3) In the case of a double drive axle, the permissible pressure determines the distance between the axles:

- if the distance between the axles of the double drive axle is less than $1 \mathrm{~m}$, the permissible load on the double axis is up to 11.5 tonnes,

- if the distance between the axles of a double drive axle is between $1 \mathrm{~m}$ and $1.3 \mathrm{~m}$, then the permissible load on the double axis is up to 16 tons.

4) The permitted pressure on a single axis, which is not a driving axis, has not exceed 10 tons.

\section{Measuring and testing subjects}

The purpose of the work is to define:

- load on the wheels and axles of the Honker M-AX modernized vehicle in comparison to the load on the wheels and axles of the Honker 2000 base car,

- load on the wheels and axles of the vehicle STAR 266M2 -Vehicle Service Workshop. The test objects are shown in Figs. 1-3. Fig. 1 shows the silhouette of a Honker M-AX personal 
and off-road car, Fig. 2 shows the silhouette of the Honker 2000 base car, and Fig. 3 shows the silhouette of the vehicle STAR 266M2 Vehicle Service Workshop. Research and measurements were carried out at the premises of Autobox Innovations Ltd. Lim. Par in Starachowice at street Car "STAR 266" 1.

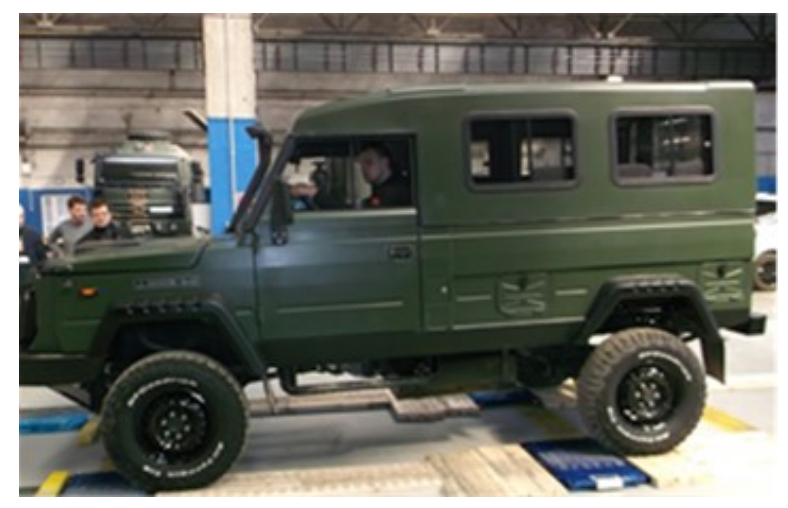

Fig. 1. Honker $M-A X$

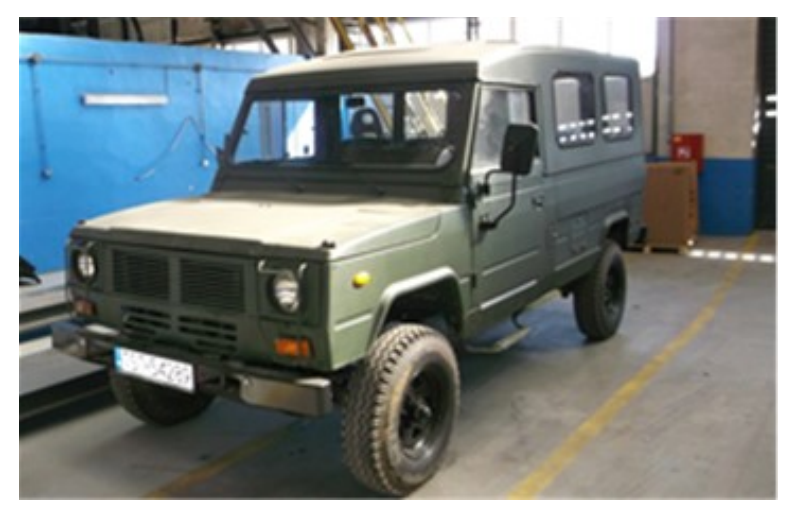

Fig. 2. Honker 2000

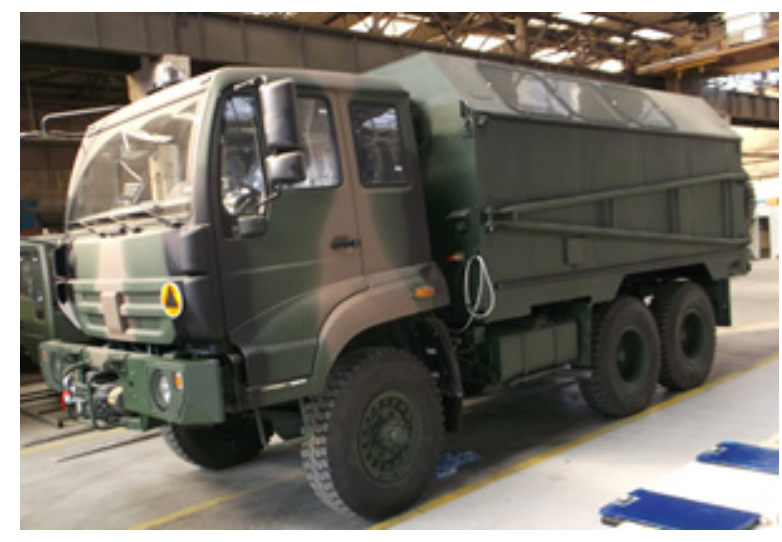

Fig. 3. STAR 266M2, Vehicle Service Workshop

\section{Measurements and tests}

During the tests, the following initial conditions were adopted:

- vehicles should be completed,

- the substrate should be flat and non-deformable,

- measuring scales, with a measuring range of not less than $5000 \mathrm{~kg}$, should be spaced so that it is possible to measure the mass on all wheels simultaneously, 
- measurements of the mass distribution should be repeated several times for each direction of approach of vehicles on scales, both front and back.

Research tasks were carried out inside the industrial hall, on levelled hard ground. During the project, depending on the type of car, four or six portable electronic scales of the Tamtron Ltd. type were used, which are shown in Fig. 4. The characteristics of scales are as follows: permissible weighing mass $-6,000 \mathrm{~kg}$, accuracy $-2 \mathrm{~kg}$. Fig. 5 presents an example of the setting of scales for testing the Honker M-AX car.

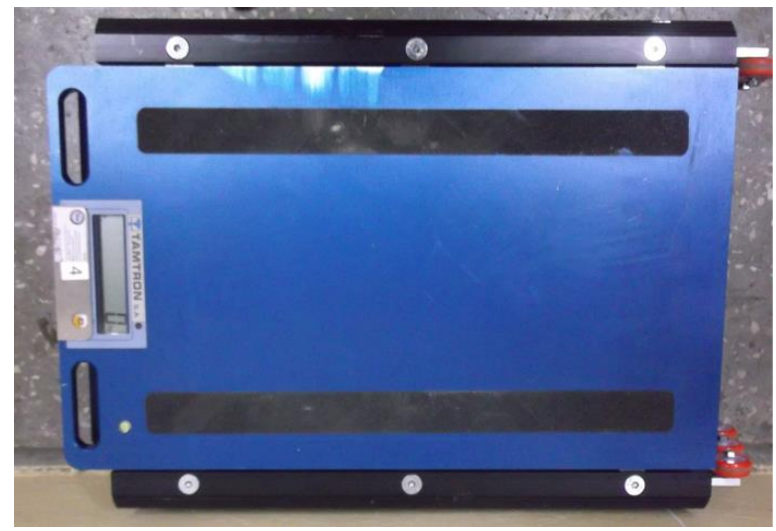

Fig. 4. Portable electronic scale

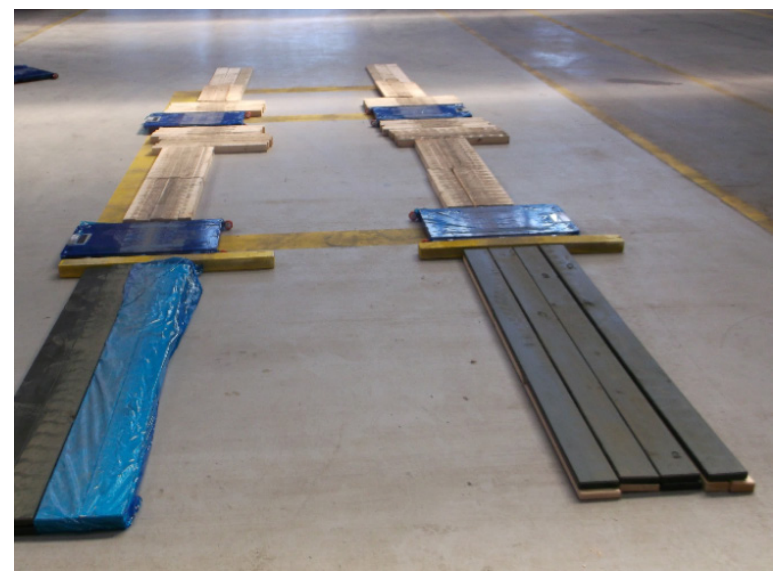

Fig. 5. Scales arrangement for Honker M-AX

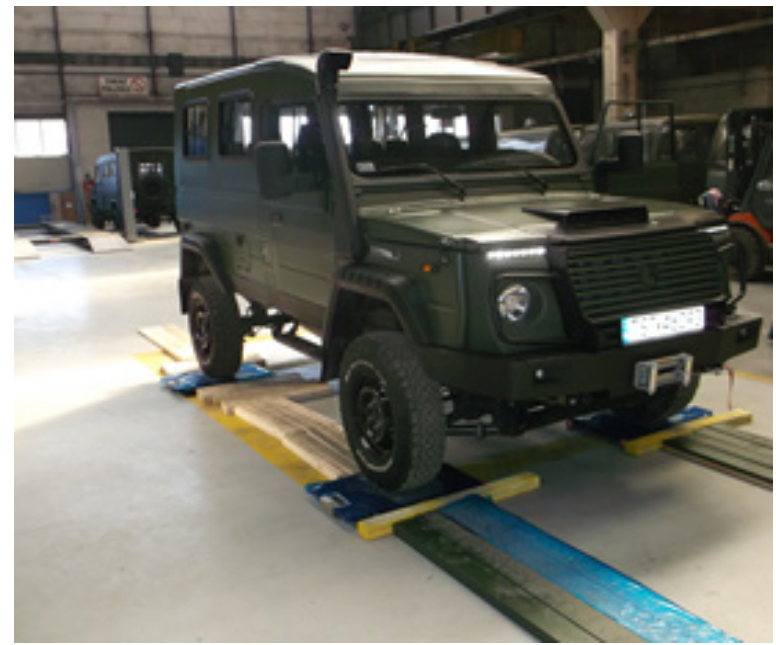

Fig. 6. Honker M-AX car on measuring platform 
Measurements were made for two variants of vehicle load, the first without load, the second with the permissible load and for two directions of approaching the vehicle on the measuring scales.

Exemplary measurement results for the Honker M-AX car are summarized in the tables. Tab. 1 presents the results of car wheel load measurements, with kerb weight, for vehicle approaching scales driving forward, while in Tab. 2, for vehicle approaching measuring scales driving backwards. Tab. 3 and 4 present the results of the measurements as above, but for the car laden to the permissible gross weight.

Tab. 1. Honker M-AX mass distribution, kerb weight, approaching scales driving forward

\begin{tabular}{|c|c|c|c|}
\hline Axis & $\begin{array}{c}\text { Left side } \\
{[\mathrm{kg}]}\end{array}$ & $\begin{array}{c}\text { Right side } \\
{[\mathrm{kg}]}\end{array}$ & $\begin{array}{c}\text { Total } \\
{[\mathrm{kg}]}\end{array}$ \\
\hline First & 812 & 738 & 1550 \\
\hline Second & 528 & 572 & 1100 \\
\hline Total $[\mathrm{kg}]$ & 1340 & 1310 & 2650 \\
\hline
\end{tabular}

Tab. 2. Honker M-AX mass distribution, kerb weight, approaching scales driving backwards

\begin{tabular}{|c|c|c|c|}
\hline Axis & $\begin{array}{c}\text { Left side } \\
{[\mathrm{kg}]}\end{array}$ & $\begin{array}{c}\text { Right side } \\
{[\mathrm{kg}]}\end{array}$ & $\begin{array}{c}\text { Total } \\
{[\mathrm{kg}]}\end{array}$ \\
\hline First & 812 & 740 & 1552 \\
\hline Second & 528 & 573 & 1101 \\
\hline Total $[\mathrm{kg}]$ & 1340 & 1313 & 2653 \\
\hline
\end{tabular}

Tab. 3. Honker M-AX mass distribution, permissible gross weight, approaching scales driving forward

\begin{tabular}{|c|c|c|c|}
\hline Axis & $\begin{array}{c}\text { Left side } \\
{[\mathrm{kg}]}\end{array}$ & $\begin{array}{c}\text { Right side } \\
{[\mathrm{kg}]}\end{array}$ & $\begin{array}{c}\text { Total } \\
{[\mathrm{kg}]}\end{array}$ \\
\hline First & 871 & 849 & 1720 \\
\hline Second & 876 & 943 & 1819 \\
\hline Total $[\mathrm{kg}]$ & 1747 & 1792 & 3539 \\
\hline
\end{tabular}

Tab. 4. Honker M-AX mass distribution, permissible gross weight, approaching scales driving backwards

\begin{tabular}{|c|c|c|c|}
\hline Axis & $\begin{array}{c}\text { Left side } \\
{[\mathrm{kg}]}\end{array}$ & $\begin{array}{c}\text { Right side } \\
{[\mathrm{kg}]}\end{array}$ & $\begin{array}{c}\text { Total } \\
{[\mathrm{kg}]}\end{array}$ \\
\hline First & 873 & 849 & 1722 \\
\hline Second & 875 & 942 & 1817 \\
\hline Total $[\mathrm{kg}]$ & 1748 & 1791 & 3539 \\
\hline
\end{tabular}

\section{Summary and final conclusions}

The weight of the vehicle and its distribution has a very large impact on driving the vehicle on a given track. With regard to special cars, it is not only important that the mass does not exceed the maximum permissible gross vehicle weight (pgw), but also appropriate weight distribution of the body and equipment and the cargo carried, to ensure a rational distribution of pressure on the wheels and axles of the vehicle. This is especially important when driving in the field on a deformable base, including adhesion and resistance to movement. In most cases, the load capacity of such a subsoil is reduced, the vehicle mass must be reduced to a level of up to $0.6 \mathrm{pgw}$. Under these conditions, the components of the chassis systems are subjected to significant dynamic loads with a high frequency of changes. This affects the traction of the vehicle, the ability 
to overcome natural and artificial obstacles, stability of driving and safety, especially in emergency or critical situations.

The data obtained from measurements and knowledge of geometry and dimensions allow determining the position of the centre of mass of the vehicle in the horizontal plane.

On the basis of the analysis of the obtained results, one can notice the high repeatability of the results during the research trials and the entry to the measuring scales with the front as well as the back. It can be unequivocally stated that mass vehicles were correctly positioned in vehicles and proper pressure distribution was obtained for wheels and axles.

\section{References}

[1] Andrzejewski, R., Stabilność ruchu pojazdów kołowych, WNT, Warszawa 1997.

[2] Rozporządzenie Ministra Infrastruktury dnia 31 grudnia 2002 r. (Dz.U.2015.305 2015.08.15 zm. Dz.U.2015.1077 § 1 2016.01.01 zm. Dz.U.2015.1966 § 1) w sprawie warunków technicznych pojazdów oraz zakresu ich niezbędnego wyposażenia.

[3] Norma Obronna NO-23-A200 2008: Wojskowe pojazdy samochodowe. Samochody wysokiej mobilności. Wymagania.

[4] Norma Obronna NO-10-A002 2005: Uzbrojenie i sprzęt wojskowy. Podstawy projektowania i badań. Wymagania dotyczace transportu drogowego.

[5] PN-ISO 612:2006: Pojazdy drogowe. Wymiary pojazdów samochodowych i pojazdów ciagniętych. Terminy $i$ definicje.

[6] Ustawa z dnia 9 kwietnia 2015 r. o zmianie ustawy - Prawo o ruchu drogowym (Dz.U. 2015 poz. 591).

Manuscript received 07 January 2019; approved for printing 21 March 2019 